medRxiv preprint doi: https://doi.org/10.1101/2021.07.06.21259924; this version posted July 7, 2021. The copyright holder for this preprint

(which was not certified by peer review) is the author/funder, who has granted medRxiv a license to display the preprint in perpetuity.

All rights reserved. No reuse allowed without permission.

\title{
Effectiveness of Ivermectin-Based Multidrug Therapy in Severe Hypoxic Ambulatory COVID-19 Patients
}

Running head: Ivermectin combo therapy treats COVID-19 patients Authors: Sabine Hazan ${ }^{1}, \mathrm{MD}^{*}$; Sonya Dave ${ }^{2}, \mathrm{PhD}$; Anoja W. Gunaratne ${ }^{3}, \mathrm{PhD}$; Sibasish Dolai ${ }^{3}$, PhD; Robert L Clancy ${ }^{3}$, MD, PhD; Peter A. McCullough, MD ${ }^{4}$, MPH, Thomas J. Borody ${ }^{3}$, MD, $\mathrm{PhD}, \mathrm{DSc}$

1. ProgenaBiome, LLC, 1845 Knoll Dr., Ventura, CA, USA, 93003

2. Microbiome Research, 1845 Knoll Dr., Ventura, CA, USA, 93003

3. Centre for Digestive Diseases, 229 Great North Road, Five Dock, NSW, Australia, 2046.

4. Texas A \& M College of Medicine, Baylor Dallas Campus, Dallas TX, USA 75226

* Corresponding Author

Authors' contributions: SH contributed to and led all aspects of the study, including idea formulation, clinical treatment, study design, Covidex design, analysis, and writing. S Dave carried out data analysis, Covidex design and validation, obtaining control, and contributed to writing. AWG, RLC, and PAM contributed to writing. S Dolai contributed to writing and study design. TJB led all aspects of the study, including idea formulation, study design and writing.

Acknowledgements: The authors would like to thank Margaux Alvaran for technical assistance.

Funding: This study was funded by ProgenaBiome, LLC.

The authors state that they have obtained appropriate institutional review board approval and have followed principles of the Declaration of Helsinki for all human experimental investigations. Informed consent has been obtained from the participants involved.

Data-sharing: The datasets used and/or analysed during the current study are available from the corresponding author on reasonable request.

Word count (intro+methods+results+discussion): 3576

Figure number: 3+ 1 Supplementary figure

Table number: 2 
medRxiv preprint doi: https://doi.org/10.1101/2021.07.06.21259924; this version posted July 7, 2021. The copyright holder for this preprint (which was not certified by peer review) is the author/funder, who has granted medRxiv a license to display the preprint in perpetuity.

All rights reserved. No reuse allowed without permission.

\begin{abstract}
Ivermectin is a safe, inexpensive and effective early COVID-19 treatment validated in 20+ RCTs. Having developed combination therapies for Helicobacter pylori, we tested various COVID-19 combinations and describe the most effective. In 24 consecutive COVID-19 subjects with high risk features, hypoxia and untreated moderate-severe symptoms averaging 9 days, we trialed this novel combination comprising ivermectin, doxycycline, zinc, and Vitamins D and C. It was highly effective. All subjects resolved symptoms in 11 days on average, and oxygen saturation improved in $24 \mathrm{hrs}(87.4 \%$ to $93.1 \%, p=0.001)$. Hospitalizations and deaths were significantly fewer ( $p<0.002$ or 0.05 , respectively) than in background-matched controls from the CDC database. Triple combination therapy is safe and effective even in moderate-severe patients with hypoxia treated in the outpatient setting.

Trial Registration: N/A, see methods.
\end{abstract}

Keywords: SARS-CoV-2, COVID, Coronavirus, Ivermectin, Doxycycline, Zinc

\title{
List of abbreviations:
}

$\chi^{2}$ test (Chi-Square Test); CDC (Center for Disease Control); CI (Confidence Interval); COVID19 (Coronavirus, SARS-COV-2); Hrs. (Hours);

HAZDpaC(Hydroxychloroquine,Azithromycin,Vit D, Zinc Pack); H. pylori (Helicobacter pylori);ICT (Ivermectin Combination Therapy); PMH (Past Medical History) ; pt (point); pts (points); SEM (Standard Error of Mean); SOB (Shortness of breath); $\mathrm{SpO}_{2}$ (Percent Saturation Peripheral Oxygen); temp (Body temperature in ${ }^{0} \mathrm{~F}$ )

\section{Declarations:}

Ethics approval and consent to participate: All subjects were explained the study and provided written informed consent. This study was approved by E\&I Review Services (https://www.eandireview.com/) as study \# 210006.

Consent for publication: All authors have read and agreed to the final submitted contents of this publication.

Availability of data and materials: The datasets used and/or analysed during the current study are available from the corresponding author on reasonable request.

Funding: This study was funded by ProgenaBiome, LLC.

Acknowledgements: The authors would like to thank Margaux Alvaran for technical assistance. 
medRxiv preprint doi: https://doi.org/10.1101/2021.07.06.21259924; this version posted July 7, 2021. The copyright holder for this preprint (which was not certified by peer review) is the author/funder, who has granted medRxiv a license to display the preprint in perpetuity. All rights reserved. No reuse allowed without permission.

\section{Introduction}

There is currently a lack of effective treatments for early or ambulatory patients with COVID-19. Patients testing positive are sent home to isolate and generally, no specific line of treatment is prescribed in this phase of the illness. However, there is growing evidence that certain repurposed drugs with good safety profiles, taken early, can significantly improve outcomes and even avoid or delay the need for immune-modulators, antiplatelet / antithrombotic therapy, and the administration of oxygen [1].

Among the most extensively studied of such COVID-19 therapeutics is ivermectin (IVM), a drug that has been used safely in 3.7 billion doses worldwide since 1987 [2-4]. Recently, Dr. Satoshi Omura, the 2015 Nobel prize co-laureate for the discovery of IVM, and colleagues comprehensively reviewed studies to date on IVM activity against COVID-19, concluding that the preponderance of the evidence demonstrated such efficacy [2]. IVM has been tested in more than 20 randomized controlled trials (RCTs) for COVID-19 treatment, with statistically highly significant clinical benefits in almost all of these and a pooled mortality reduction of $78 \%$ for the treatment vs. control groups [5]. Five such studies for IVM treatment of COVID-19 recently published in top-tier medical journals have all shown multiple clinical benefits for IVM vs. controls, most of these with high statistical significance on the order of $p<0.002$ [6-10]. IVM is well tolerated at much greater than the standard single dose of $200 \mu \mathrm{g} / \mathrm{kg}[11,12]$ and has been used in RCTs for COVID-19 treatment at cumulative doses of $1,500 \mu \mathrm{g} / \mathrm{kg}$ [13], 1,600 $\mu \mathrm{g} / \mathrm{kg}$ [14], and 3,000 $\mu \mathrm{g} / \mathrm{kg}$ [15] over 4 or 5 days either without or with mild and transient adverse effects. Not surprisingly, IVM has become extensively used in the prevention and early disease management of COVID-19, particularly in non-Western countries. 
medRxiv preprint doi: https://doi.org/10.1101/2021.07.06.21259924; this version posted July 7, 2021. The copyright holder for this preprint (which was not certified by peer review) is the author/funder, who has granted medRxiv a license to display the preprint in perpetuity. All rights reserved. No reuse allowed without permission.

Despite this strong evidence of clinical benefit in COVID-19 for IVM therapy, variation in therapeutic regimens especially with respect to addition of a broad spectrum antibiotic and zinc, has led to confusion as to how best to manage acute infections. Indeed, the most impressive of the early ambulatory multi-drug therapy, claiming $87 \%$ and $75 \%$ reductions in hospitalization and deaths, respectively, both with a $\mathrm{P}$ value of 0.001 , in 869 high risk subjects, left optimal management strategy unclear due to a mixed use of IVM and hydroxychloroquine (HCQ) [16]. There is an immediate need for an effective, safe, and practically available combination therapy formulated on the basis of the best available data.

At a cellular level, IVM modulates communication between the cytoplasm and nucleus, creating a hostile environment for assemblage of virus, while at the same time reducing cytokinemediated inflammation. In addition, IVM inhibits pathology following infection with the COVID-19 virus, by specifically blocking binding of the virus "Spike" protein to the ACE2 receptor. Finally, IVM has been associated with favorable changes in cellular innate immunity [17].

Our group has been developing antiviral drug combinations for COVID-19 and found IVM to be particularly effective as a co-therapy for use early in COVID-19 to shorten the time to symptom resolution and to prevent hospitalization. IVM used alone can at times be only partially effective but not curative $[6,1,19]$ yet a higher dose of IVM plus azithromycin and zinc has achieved a 92\% mortality reduction vs. controls [14]. Thus, we chose a combination of safe and widely available medications, approved for other indications and without drug-drug interactions or QT prolongation that inhibits intracellular virus replication and possess some anti-inflammatory properties. 
medRxiv preprint doi: https://doi.org/10.1101/2021.07.06.21259924; this version posted July 7, 2021. The copyright holder for this preprint (which was not certified by peer review) is the author/funder, who has granted medRxiv a license to display the preprint in perpetuity.

All rights reserved. No reuse allowed without permission.

The use of combination therapy for intracellular bacterial infections is not new and has been used successfully to treat Tuberculosis, Helicobacter pylori infections, leprosy and intracellular viral infections such as Hepatitis $B \& C$ - where a single component of the combination therapies is rarely curative. In some viral infections e.g. HIV, even combined multiple antiviral drugs cannot completely cure but suppress the viral load perpetually. IVM is best known for its broadspectrum efficacy for parasite infections, its high cure rate and limited drug resistance when used in combination [20]. Although useful, IVM used alone is not the 'magic bullet'. Combinations can help lower individual doses and reduce side effects. To cover all age group requirements, we combined IVM with doxycycline and zinc as active components and with Vitamins D and C as replacement 'excipients' given to supplement common clinical deficiencies in the aged.

This study reports the use of the above combination therapy in consecutive, ambulatory, complex, at times profoundly hypoxic patients whose oxygen saturation $\left(\mathrm{SpO}_{2}\right)$ was as low as 73\%. Participants were treated by an experienced clinical trials team within Ventura Clinical Trials Inc..

\section{Methods:}

\section{Subjects:}

Subjects were identified from patients referred by physicians, or word-of-mouth in Los Angeles, Ventura County, CA, and other states in the USA. These patients were referred to participate in clinical trials under clinicaltrials.gov ID NCT04482686 (which is a double-blind Randomized Control Trial). However some did not qualify for this trial as their oxygen saturation was less than $90 \%$, and were deemed too sick to enter a placebo-controlled trial. Given they were excluded and refused to go to the hospital, they were treated off-label via telemedicine, during Aug. 2020 and Feb. 2021. Subjects were given the opportunity to participate in this open label 
medRxiv preprint doi: https://doi.org/10.1101/2021.07.06.21259924; this version posted July 7, 2021. The copyright holder for this preprint (which was not certified by peer review) is the author/funder, who has granted medRxiv a license to display the preprint in perpetuity.

All rights reserved. No reuse allowed without permission.

trial with IRB oversight once the diagnosis was made via swab RT-qPCR testing once the diagnosis was made via swab RT-qPCR testing. Inclusion criteria were as follows 1) positive PCR for COVID-19; 2) informed consent; 3) age $\geq 18$ years, and 4) agreement to practice two highly effective methods of birth control if of childbearing potential. Exclusion criteria included 1) allergies or drug interactions with the combination therapy components; 2) listed comorbidities, including seizure risk; and 3) pregnancy.

\section{Treatment:}

Treatment began as soon as practical, within 72 hrs. of patients presenting to Ventura Clinical Trials. All screened subjects met the inclusion criteria and were enrolled consecutively. Treatment was defined as 'IVM Combination Therapy' (ICT) and consisted of ten days of oral: Doxycycline (100mg twice a day), IVM (12mg on day 1 , day 4, and day 8), Zinc (25mg twice a day), Vitamin $\mathrm{D}_{3}$ (1500 IU twice a day) and Vitamin $\mathrm{C}$ (1500mg twice a day). ICT was given daily for ten days only.

Two patients (\#10 and \#23) received an initial treatment on day one of $36 \mathrm{mg}$ IVM (rather than $12 \mathrm{mg}$ ) due to particularly low $\mathrm{SpO}_{2}$ or expected clinical need.

\section{Monitoring:}

Subjects self-recorded symptoms in their daily logs (supplementary 1) for the first 10 days. Electrocardiograms (EKGs), blood pressure, temperature (reported in ${ }^{0} \mathrm{~F}$ ) and $\mathrm{SpO}_{2}$, were collected via provided medical equipment at home. On days 1, 5, 10 and 30, SARS-CoV-2 testing swabs were self-collected by subjects and sent to pathology for testing. Pregnancy tests were performed as appropriate. 
medRxiv preprint doi: https://doi.org/10.1101/2021.07.06.21259924; this version posted July 7, 2021. The copyright holder for this preprint (which was not certified by peer review) is the author/funder, who has granted medRxiv a license to display the preprint in perpetuity.

Endpoints:

Endpoints were 1) time from presentation to negative SARS-CoV-2 PCR; 2) time from presentation to symptom resolution; 3) progression to hospitalization; 4) patient survival.

\section{Externally Controlled Trial (ECT) Arm:}

Given the challenges for COVID-19 of enrolling high risk severely hypoxic patients in an openlabel trial with an untreated control arm, our treated group arm survival was compared to the control group survival rate in the general population. This ECT, also known as a synthetic control arm, was calculated from the public CDC database of COVID-19 subjects [21]. Available information includes age range, presence of any chronic condition (COVID-19vulnerability or otherwise, conditions not specified), date of infection, and whether the COVID19 diagnosis was laboratory-confirmed. We used information from all subjects who met the following criteria: 1) age 50+ years; 2) laboratory-confirmed COVID-19 diagnosis; 3) death/survival, race, and sex status available and known; 4) infection prior to March 2021; and 5) subject had any co-morbidities. This synthetic control arm development was carried out after our clinical data were obtained, and so selection criteria chose the control subjects closely matched to the subjects in our study, all of whom had some underlying condition and a large majority were over 50 years of age. The CDC database was analysed using CSViewer vs. 1.3 (EasyMorph Inc, Toronto, ON, CA, http://easymorph.com).

\section{$\underline{\text { Covidex calculations and statistics: }}$}


medRxiv preprint doi: https://doi.org/10.1101/2021.07.06.21259924; this version posted July 7, 2021. The copyright holder for this preprint (which was not certified by peer review) is the author/funder, who has granted medRxiv a license to display the preprint in perpetuity. All rights reserved. No reuse allowed without permission.

Covidex and Covidex-F are ambulatory SARS-CoV-2 infection disease severity measures that we developed and validated in this study. They are weighted particularly to emphasize $\mathrm{SpO}_{2}$, and Covidex-F includes a variable for body temperature.

Covidex score $=1$ pt. (if history of sleep apnea) +1 pt. (if history of COPD) +1 pt. (if history of cardiovascular disease) $+1 \mathrm{pt}$. (if history of asthma) $+1 \mathrm{pt}$ (if history of prior clots, ischemia or stroke) +1 pt (if obese, i.e. $30 \mathrm{~kg} / \mathrm{m}^{2}<\mathrm{BMI}<40 \mathrm{~kg} / \mathrm{m}^{2}$ ) +2 pts (if severely obese, i.e. BMI $\geq 40$ ) $+1 \mathrm{pt}$ (if age $\geq 60$ years $)+\left[95-\left(\mathrm{SpO}_{2}\right.\right.$ as a percentage $\left.)\right] p t s$. For instance, a hypothetical patient with a history of asthma and morbid obesity with a $\mathrm{SpO}_{2}$ prior to treatment of $85 \%$ would have a Covidex score of 1 (for asthma) +2 (for obesity) +10 (for $\left.\mathrm{SpO}_{2} \mathrm{of} 85 \%\right)=12$ pts.

Covidex-F score $=$ Covidex score +1 pt. (if temperature on presentation between $99.5^{\circ} \mathrm{F}$ and $100.4{ }^{0} \mathrm{~F}$ ) +2 pts. (if temp on presentation between $100.4^{0} \mathrm{~F}$ and $103.5^{\circ} \mathrm{F}$ ) +3 pts. (if temp on presentation $\left.\geq 103.5^{0} \mathrm{~F}\right)$.

Best-fit lines were made to assess the correlation between Covidex scores and time from treatment to symptom resolution. Regression was carried out in Prism version 8 (GraphPad Prism software for Windows, San Diego, California USA, www.graphpad.com) using least square regression without weighting or special handling of outliers. All graphs were prepared by and statistical analysis done using GraphPad Prism version 8, and the error bar are indicative of the standard error of the mean (SEM).

\section{Results:}

Table 1 lists all subjects in the study, two of which did not consent to ICT treatment (subjects \#10 and \#26), and their associated race, gender, symptoms, fever, and other clinical notes. All subjects had COVID-19-related symptoms on presentation, and the symptom range was broad with several showing shortness of breath (SOB). The vast majority of subjects, 21 of 24 
medRxiv preprint doi: https://doi.org/10.1101/2021.07.06.21259924; this version posted July 7, 2021. The copyright holder for this preprint (which was not certified by peer review) is the author/funder, who has granted medRxiv a license to display the preprint in perpetuity.

All rights reserved. No reuse allowed without permission.

$(87.50 \%)$, had fever on presentation with a mean temperature for all 24 subjects of $101.2 \pm 0.32$ ${ }^{0}$ F. Specifically, $1 / 24(4.17 \%)$ had low grade fever (99.5-100.4), 18/24 (75.00\%) had medium grade fever (100.5-103.4), and 2/24 (8.33\%) had high grade fever $(\geq 103.4){ }^{0} \mathrm{~F}$.

Table 2 summarizes the demographics and past medical history (PMH) of subjects who consented to treatment (total $n=24,2$ additional subjects who declined treatment are excluded). Notably, patients were older (a known COVID-19 vulnerability) with a mean age of $66 \pm 2.75$ years, and a range of 43 to 94 years (Table 2A). The population of the 24 subjects consenting to treatment (not subjects \#10 and \#26, Table 1) was 63\% males. Death of untreated subjects \#10 and \#26 excluded downstream analysis in the other figures.

Table 2B lists the number of patients who had comorbidities associated with COVID-19 vulnerability, based on CDC guidelines[22]. These comorbidities are chronic kidney disease, chronic obstructive pulmonary disease (COPD), Down syndrome, cardiovascular disease, immunocompromised state including HIV, obesity (body mass index [BMI] of $30 \mathrm{~kg} / \mathrm{m}^{2}$ or higher but $<40 \mathrm{~kg} / \mathrm{m}^{2}$ ), severe obesity (BMI $\geq 40 \mathrm{~kg} / \mathrm{m}^{2}$ ), pregnancy, sickle cell disease, smoking, type 2 diabetes. Of note, no subjects had cancer, Down syndrome, or sickle cell disease and none were pregnant nor were smokers.

Many subjects had multiple comorbidities associated with COVID-19 vulnerability, as outlined in Table 2B. In total, 11/24 (45.83\%) subjects had COVID-19-vulnerable comorbidities of which $3(12.50 \%)$ had 2 separate comorbidities, and $2(8.33 \%)$ had 3 co-morbidities.

A minority of subjects $(n=7)$ had other COVID-19 treatment(s) prior to and/or during ICT administration, namely Remdesivir ( $\mathrm{n}=1$ subject), involvement in a placebo-controlled trials of HAZDpaC ( $\mathrm{n}=4$ subjects, trial clinicaltrials.gov NCT04334512; may have been given treatment or placebo) and hydroxychloroquine (HCQ, $\mathrm{n}=3$ subjects). 
medRxiv preprint doi: https://doi.org/10.1101/2021.07.06.21259924; this version posted July 7, 2021. The copyright holder for this preprint (which was not certified by peer review) is the author/funder, who has granted medRxiv a license to display the preprint in perpetuity. All rights reserved. No reuse allowed without permission.

Fig. 1 demonstrates all subjects recovered from COVID-19, typically within one to two weeks. Fig. 1A shows various durations for each subject and average values (one outlier excluded). Time from onset of symptoms to treatment initiation is shown in column 1 and averages $9.2 \pm$ 2.1 days. Time from start of treatment to symptom resolution was11.6 \pm 1.4 days. Time from first positive to first negative PCR was $16.9 \pm 1.6$ days and is less than three weeks. Time from start of treatment to first negative PCR was $11.5 \pm 1.6$ days and is also less than three weeks.

Fig. 1B shows that $100 \%$ of subjects survived COVID-19, without need for hospitalization or ventilator use. As noted in Table 2, many of these subjects were older and with comorbidities. When compared to the synthetic control arm, derived from the CDC database (see methods, and as follows), this was a significant increase in survival rate $(p=0.044)$ and decrease in hospitalization rate $(p=0.0011)$, evaluated via $\chi^{2}$ test. Of note, the patients in this CDC database likely did receive treatment, of an unknown nature. Thus, the survival rate of this synthetic control reflects the "typical" survival rate in the USA, which is significantly less than the $100 \%$ survival rate observed on ICT.

The $100 \%$ survival rate on ICT was compared with survival rates from the CDC database of COVID-19 subjects. 356,424 control subjects were obtained, based on qualification criteria described in the methods section. These criteria focused on older subjects (50+ years), similar to our study population, that also had underlying conditions. One should note that the underlying condition criteria information available in this database refers to chronic conditions of any type, whether or not the condition induces COVID-19-vulnerability. With this definition, $100 \%$ of control subjects and ICT-treated subjects had underlying conditions of any type.

Our critical finding in Fig. 2 (see also Table 2), showed that 23/24 patients were hypoxic with $\mathrm{SpO}_{2}<90 \%$. Some subjects consenting to treatment had $\mathrm{SpO}_{2}$ as low as $73 \%, 77 \%$, $84 \%$ and 
medRxiv preprint doi: https://doi.org/10.1101/2021.07.06.21259924; this version posted July 7, 2021. The copyright holder for this preprint (which was not certified by peer review) is the author/funder, who has granted medRxiv a license to display the preprint in perpetuity. All rights reserved. No reuse allowed without permission.

$85 \%$ on presentation. As a whole, shown in Fig. $2 \mathrm{~A}$, the $\mathrm{SpO}_{2}$ of subjects was significantly less than $95 \%$, the defined point of cure $\left(95 \%\right.$ CI of mean $\mathrm{SpO}_{2}=85.5$ to 89.4 , Mean $=87.4 \pm$ 0.93\%). Subjects' $\mathrm{SpO}_{2}$ increased within 24 hrs. of treatment. Their mean $\mathrm{SpO}_{2}$ before treatment (for subjects with data before and after $24 \mathrm{hrs}$.) was $86.5 \% \pm 1.3$, and after $24 \mathrm{hrs}$. of treatment, $93.1 \% \pm 0.63$, a highly significant and rapid increase $(\mathrm{p}<0.001) . \mathrm{SpO}_{2}$ then continued to rise. Treatment continued for 10 days reaching the point of successful treatment or cure, which was $\mathrm{SpO}_{2}>95 \%$. Successful treatment was reached for all subjects. That is, there was a $100 \%$ restoration rate in terms of $\mathrm{SpO}_{2}$. No patient who accepted treatment required hospitalization.

Two subjects (\#10 and \#26) declined treatment. These subjects did not recover $\mathrm{SpO}_{2}$ and died from COVID-19 infection. An adverse drug event of dizziness was reported by one subject, who nevertheless continued with treatment successfully otherwise.

Fig. 3 shows the validation of the Covidex and Covidex-F scores we developed, defined in our methods. These scores provide an index of COVID-19 predicted severity, based on past medical history, $\mathrm{O}_{2}$ just before treatment and fever grade on presentation. The mean Covidex score was $10.34 \pm 1.08$ and the mean Covidex-F score was $11.63 \pm 1.13$, with $87 \%$ and $85 \%$ of the score points, respectively, coming from the contribution of the $\mathrm{SpO}_{2}$ term. In other words, approximately 80 to $90 \%$ of this score is weighted towards $\mathrm{SpO}_{2}$. It should also be noted, the $\mathrm{PMH}$ aspects that contribute to this score emphasize respiratory, cardiovascular, and obesity histories and differ from CDC defined COVID-19-vulnerabilities.

Covidex and Covidex-F are both plotted vs. time from treatment to symptom resolution. Both shows statistically significant correlations (Covidex: $p=0.0096, r^{2}=0.2078$; Covidex-F: $p=$ 0.0288, $r^{2}=0.2790$ ), indicating that either Covidex or Covidex-F is associated with and may predict time to symptom resolution. 
medRxiv preprint doi: https://doi.org/10.1101/2021.07.06.21259924; this version posted July 7, 2021. The copyright holder for this preprint

\section{Discussion:}

We report for the first time a highly effective ICT which led to $100 \%$ survival and cure in unselected ambulatory 'moderate to severely' ill COVID-19 patients with hypoxia managed as outpatients. Given our experience developing combination therapies for $H$. pylori, we trialed a number of different IVM-based combinations on ambulatory COVID-19 patients, searching for a cure, and found the above combination to be the best as a 'foundation therapy' for COVID 19. Understanding that a personalized approach may require added HCQ or other components in some patients much like H.pylori resistant to triple therapy sometimes requires quadruple therapy. Hypoxia is a demonstrated predictor of COVID-19 mortality [23]. For example, several of these patients had profound hypoxia, measured by oximetry, at $73 \%, 77 \%, 84 \%$ and $85 \%$ on presentation. Despite a symptom to treatment delay of 9.2 days, our treatment brought rapid improvement - beginning in some within 12 hrs. with a mean $\mathrm{SpO}_{2}$ rising from 86.5 to 93.1 in the first 24 hrs. There was a parallel improvement in the symptoms including loss of cough, fever and tiredness. Also, the time from the start of treatment to the first negative PCR averaged $11.5 \pm$ 1.6 days. Generally, such ill patients would have been admitted to the hospital, yet all those treated with the ICT avoided hospitalization and none died.

Turning to the ECT 'synthetic control arm' it is clear that the ICT was statistically superior to the control arm even though a small patient group was reported. The very low adverse effects from reported studies and this treatment group supports the use of ICT if clinical symptoms and risk factors for COVID-19 progression are present, even in cases with PCR pending results. ECT 
medRxiv preprint doi: https://doi.org/10.1101/2021.07.06.21259924; this version posted July 7, 2021. The copyright holder for this preprint (which was not certified by peer review) is the author/funder, who has granted medRxiv a license to display the preprint in perpetuity.

All rights reserved. No reuse allowed without permission.

arms are now increasingly used, especially where the control arm or 'standard-of-care' arm may have a fatal outcome[24].

The rationale for using combination antiviral therapy is based on our growing understanding that intracellular infections - bacterial or viral, cannot be reliably cured using a single drug. It is also based on our knowledge that IVM resistance is common. Hence, there is no single 'silver bullet' for COVID-19, and the indiscriminate use of IVM alone could induce COVID-19 resistance by generating drug-resistant strains. Resistance to IVM was the case when used alone in scabies, nematodes, strongyloidiasis, microfilaridermias, onchocerca and volvulus [19,25-31]. We are now seeing resistance develop even in combined therapies using two antibiotics for $H$. pylori. This teaches us to use IVM in COVID-19 only in combination therapies, especially so, with growing reports of mutant strains resulting in vaccine breakthrough infections [32]. Hence, the proposed combination therapy was developed to induce cure more rapidly, prevent resistance, and overcome mutant strain emergence - no replication no mutation.

Regarding strategies in the development of combination therapies, intracellular coronavirus replication requires several active drugs to inhibit viral replication. IVM, doxycycline and zinc all individually inhibit coronavirus replication and, although there are other candidates, we have proposed the above combination based on efficacy, component safety profiles, inexpensive nature, and lack of drug-drug interaction. The combination of IVM and doxycycline has also been demonstrated to act in synergy against COVID-19 [33]. This combination also appears to overcome the need for high doses of IVM identified by Caly and colleagues when used alone[34]. Further, given that zinc plays a key role in antiviral activity [34536] it would combine well with the ionophores (IVM and doxycycline) to increase its intracellular concentration and expedite viral clearance [37]. We have also assessed drug-drug interactions and found that the 
medRxiv preprint doi: https://doi.org/10.1101/2021.07.06.21259924; this version posted July 7, 2021. The copyright holder for this preprint (which was not certified by peer review) is the author/funder, who has granted medRxiv a license to display the preprint in perpetuity. All rights reserved. No reuse allowed without permission.

combination of zinc with IVM and doxycycline has no reported interactions. Additionally, each of these drugs has a low adverse side effects profile and no QT prolongation as reported with azithromycin.

Overall, based on the current literature, a 10-day combination therapy of IVM, doxycycline and zinc will not only improve symptoms [6,7] but also accelerate recovery from COVID-19. We have chosen a safe IVM dosage approved for parasites of 36mg over 10 days, and this dose has been shown to be both effective and safe in COVID-19 treatments [38]. The staggered IVM dosage over 10 days is proposed based on the half-life clearance of the drug in plasma (up to 66 hrs.)[39]. The proposed duration would allow constant availability of adequate plasma level IVM to facilitate zinc entry into the cells. Hence, the above rationale explains why some publications have already shown that IVM alone is not adequate to cure COVID-19 [6,18,19] while a multidrug regimen is likely to be more efficacious [40].

While underpowered, this study enrolled consecutive subjects into study and did not bias subject selection from different time points. Many of the enrolled subjects were profoundly ill with subjective assessments that may have resulted in hospital admission and/or intubation. Yet, ICT anti-viral activity appears to have rapidly restored $\mathrm{SpO}_{2}$ and reversed other symptoms which could not be explained simply by the developing immunity.

A weakness of this study is the lack of a concomitantly enrolled control arm. However, given the potential fatal outcomes Tess Lawrie et al. indicated [41] it is no longer ethical to approve the use of a control arm as so many profoundly ill patients in the control arm would die', as did our two subjects who declined treatment [42]. Hence our study has made use of the ECT or 'synthetic' control arm which has enabled us to make matched age and comorbidity comparisons. Institutional Review Boards should now include the provision to include available 
medRxiv preprint doi: https://doi.org/10.1101/2021.07.06.21259924; this version posted July 7, 2021. The copyright holder for this preprint (which was not certified by peer review) is the author/funder, who has granted medRxiv a license to display the preprint in perpetuity.

All rights reserved. No reuse allowed without permission.

synthetic arms and reject trials that include in a COVID-19 trial a control arm as published by Lawrie[41].

This study builds on an extensive literature, to provide a practical inexpensive, safe, readily available and highly effective triple therapy aiming to prevent resistance and one that can confidently be used as a routine treatment for outpatient COVID-19. 
medRxiv preprint doi: https://doi.org/10.1101/2021.07.06.21259924; this version posted July 7, 2021. The copyright holder for this preprint

(which was not certified by peer review) is the author/funder, who has granted medRxiv a license to display the preprint in perpetuity.

All rights reserved. No reuse allowed without permission.

\section{$\underline{\text { References }}$}

1. McCullough PA, Zelenko V, Alexander PE, Arvinte C, Bain AF, Bartlett RP, et al. 2020. Multifaceted highly targeted sequential multidrug treatment of early ambulatory high-risk SARSCoV-2 infection (COVID-19). Rev Cardiovasc Med. 30;21(4):517-530. https://doi.org/10.31083/j.rcm.2020.04.264.

2. Yagisawa M, Foster PJ, Hanaki H, Ōmura S. 2021. Global trends in clinical studies of ivermectin in COVID-19. Jpn J Antibiot. 74(1):44-94.

3. Campbell WC. 2012. History of avermectin and ivermectin, with notes on the history of other macrocyclic lactone antiparasitic agents. Curr Pharm Biotechnol. 13(6):853-65. https://doi.org/10.2174/138920112800399095.

4. Crump A, Ōmura S. 2011. Ivermectin, 'wonder drug' from Japan: the human use perspective. Proc Jpn Acad Ser B Phys Biol Sci. 87(2):13-28. https://doi.org/10.2183/pjab.87.13

5. Hill A, Abdulamir A, Ahmed S, Babalola OE, Basri R, Chachar AZK, et al. 2021. Meta-analysis of randomized trials of ivermectin to treat SARS-CoV-2 infection. Research Square. https://doi.org/10.21203/rs.3.rs-148845/v1

6. Chaccour C, Casellas A, Blanco-Di Matteo A, Pineda I, Fernandez-Montero A, Ruiz-Castillo P, et al. 2021. The effect of early treatment with ivermectin on viral load, symptoms and humoral response in patients with non-severe COVID-19: A pilot, double-blind, placebo-controlled, $\begin{array}{llll}\text { randomized } & \text { clinical } & \text { trial. } & \text { EClinicalMedicine. }\end{array}$ https://doi.org/10.1016/j.eclinm.2020.100720

7. Mahmud R, Rahman MM, Alam I, Ahmed KGU, Kabir AKMH, Sayeed SKJB, et al. 2021. Ivermectin in combination with doxycycline for treating COVID-19 symptoms: a randomized trial. J Int Med Res. 49(5):3000605211013550. https://doi.org/10.1177/03000605211013550.

8. Okumuş N, Demirtürk N, Çetinkaya RA, Güner R, Avcı IY, Orhan S, et al. 2021. Evaluation of the effectiveness and safety of adding ivermectin to treatment in severe COVID-19 patients. BMC Infect Dis. 21(1):411. https://doi.org/10.1186/s12879-021-06104-9.

9. Samaha AA, Mouawia H, Fawaz M, Hassan H, Salami A, Bazzal AA, et al. 2021. Effects of a Single Dose of Ivermectin on Viral and Clinical Outcomes in Asymptomatic SARS-CoV-2 Infected Subjects: A Pilot Clinical Trial in Lebanon. Viruses. 13(6):989. https://doi.org/10.3390/v13060989.

10. Shahbaznejad L, Davoudi A, Eslami G, Markowitz JS, Navaeifar MR, Hosseinzadeh F, et al. 2021. Effect of ivermectin on COVID-19: A multicenter double-blind randomized controlled clinical trial. Clin. Ther. https://doi.org/10.1016/j.clinthera.2021.04.007

11. Navarro M, Camprubí D, Requena-Méndez A, Buonfrate D, Giorli G, Kamgno J, et al. 2020. Safety of high-dose ivermectin: a systematic review and meta-analysis. J Antimicrob Chemother. 75(4):827-34. https://doi.org/10.1093/jac/dkz524.

12. Guzzo CA, Furtek CI, Porras AG, Chen C, Tipping R, Clineschmidt CM, et al. 2002. Safety, tolerability, and pharmacokinetics of escalating high doses of ivermectin in healthy adult subjects. J Clin Pharmacol. 42(10):1122-33. https://doi.org/10.1177/009127002401382731.

13. López-Medina E, López P, Hurtado IC, Dávalos DM, Ramirez O, Martínez E, et al. 2021. Effect of Ivermectin on Time to Resolution of Symptoms Among Adults With Mild COVID-19: A Randomized Clinical Trial. JAMA. 325(14):1426-35. https://doi.org/10.1001/jama.2021.3071.

14. Elgazzar A, Hany B, Abo Youssef S, Hafez M, Moussa H, Eltaweel A, et al. 2020. Efficacy and Safety of Ivermectin for Treatment and prophylaxis of COVID-19 Pandemic. Research Square. https://doi.org/10.21203/rs.3.rs-100956/v1.

15. Krolewiecki A, Lifschitz A, Moragas M, Travacio M, Valentini R, Alonso DF, et al. 2020. Antiviral effect of high-dose ivermectin in adults with COVID-19: a pilot randomised, controlled, open label, multicentre trial. https://doi.org/10.2139/ssrn.3714649.

16. Procter BC, Ross C, Pickard V, Smith E, Hanson C, McCullough PA. 2020. Clinical outcomes after early ambulatory multidrug therapy for high-risk SARS-CoV-2 (COVID-19) infection. Rev Cardiovasc Med. 21(4):611-614. https://doi.org/10.31083/j.rcm.2020.04.260. 
medRxiv preprint doi: https://doi.org/10.1101/2021.07.06.21259924; this version posted July 7, 2021. The copyright holder for this preprint (which was not certified by peer review) is the author/funder, who has granted medRxiv a license to display the preprint in perpetuity.

All rights reserved. No reuse allowed without permission.

17. Zaidi AK, Dehgani-Mobaraki P. 202. The mechanisms of action of Ivermectin against SARSCoV-2: An evidence-based clinical review article. J Antibiot (Tokyo). 1-13. doi: 10.1038/s41429-021-00430-5.

18. Schmith VD, Zhou JJ, Lohmer LRL. 2020. The Approved Dose of Ivermectin Alone is not the Ideal Dose for the Treatment of COVID-19. Clin Pharmacol Ther. 108(4):762-5. https://doi.org/10.1002/cpt.1889.

19. Chahla RE, Ruiz LM, Mena T, Brepe Y, Terranova P, Ortega ES, et al. 2021. Cluster Randomised Trials - Ivermectin Repurposing For COVID-19 Treatment Of Outpatients With Mild Disease In Primary Health Care Centers. https://doi.org/10.21203/rs.3.rs-495945/v1.

20. Shoop WL. 1993. Ivermectin Resistance. Parasitol Today. 9(5):154-9. https://doi.org/10.1016/0169-4758(93)90136-4.

21. Data.CDC.gov: Available from: https://data.cdc.gov/Case-Surveillance/COVID-19-CaseSurveillance-Public-Use-Data-with-Ge/n8mc-b4w4; accessed May 21st, 2021

22. CDC. COVID-19: Available from: https://www.cdc.gov/coronavirus/2019-ncov/need-extraprecautions/people-with-medical-conditions.html; accessed April 12th, 2021.

23. Mejía F, Medina C, Cornejo E, Morello E, Vásquez S, Alave J, et al. 2020. Oxygen saturation as a predictor of mortality in hospitalized adult patients with COVID-19 in a public hospital in Lima, Peru. PLoS One. 15(12):e0244171. https://doi.org/10.1371/journal.pone.0244171.

24. Ventz S, Lai A, Cloughesy TF, Wen PY, Trippa L, Alexander BM. 2019. Design and Evaluation of an External Control Arm Using Prior Clinical Trials and Real-World Data. Clin Cancer Res. 25(16):4993-5001. https://doi.org/10.1158/1078-0432.CCR-19-0820.

25. Ashraf M, Gue CL, Baddour LM. 1996. Case report: strongyloidiasis refractory to treatment with ivermectin. Am J Med Sci. 311(4):178-9. doi: 10.1097/00000441-199604000-00005.

26. Shikiya K, Zaha O, Niimura S, Uehara T, Ohshiro J, Kinjo F, et al. 1994. Clinical study on ivermectin against 125 strongyloidiasis patients. Kansenshogaku Zasshi. 68(1):13-20. Japanese. https://doi.org/10.11150/kansenshogakuzasshi1970.68.13.

27. Shikiya K, Zaha O, Niimura S, Nakamura H, Nakayoshi T, Kochi A, et al. 1992. Clinical study of eradicated and resistant patients to treatment with ivermectin for strongyloidiasis. Kansenshogaku Zasshi. 66(7):935-43. Japanese. https://doi.org/10.11150/kansenshogakuzasshi1970.66.935.

28. Mounsey KE, Holt DC, McCarthy JS, Currie BJ, Walton SF. 2009. Longitudinal evidence of increasing in vitro tolerance of scabies mites to ivermectin in scabies-endemic communities. Arch Dermatol. 145(7):840-1. https://doi.org/10.1001/archdermatol.2009.125.

29. van den Hoek JA, van de Weerd JA, Baayen TD, Molenaar PM, Sonder GJ, van Ouwerkerk IM, et al. 2008. A persistent problem with scabies in and outside a nursing home in Amsterdam: indications for resistance to lindane and ivermectin. Euro Surveill. 27;13(48):19052. https://doi.org/10.2807/ese.13.48.19052-en.

30. Awadzi K, Boakye DA, Edwards G, Opoku NO, Attah SK, Osei-Atweneboana MY, et al. 2004. An investigation of persistent microfilaridermias despite multiple treatments with ivermectin, in two onchocerciasis-endemic foci in Ghana. Ann Trop Med Parasitol. 98(3):231-49. https://doi.org/10.1179/000349804225003253.

31. Amanzougaghene N, Fenollar F, Nappez C, Ben-Amara A, Decloquement P, Azza S, Bechah Y, Chabrière E, Raoult D, Mediannikov O. 2018 Complexin in ivermectin resistance in body lice. PLoS Genet. 14(8):e1007569. doi: 10.1371/journal.pgen.1007569.

32. Hacisuleyman E, Hale C, Saito Y, Blachere NE, Bergh M, Conlon EG, et al. 2021. Vaccine Breakthrough Infections with SARS-CoV-2 Variants. N Engl J Med. NEJMoa2105000. https://doi.org/10.1056/NEJMoa2105000.

33. Maurya DK. 2020. A Combination of Ivermectin and Doxycycline Possibly Blocks the Viral Entry and Modulate the Innate Immune Response in COVID-19 Patients. Preprint. https://doi.org/10.26434/chemrxiv.12630539.v1

34. Caly L, Druce JD, Catton MG, Jans DA, Wagstaff KM. 2020. The FDA-approved drug ivermectin inhibits the replication of SARS-CoV-2 in vitro. Antiviral Res. 178:104787. https://doi.org/10.1016/j.antiviral.2020.104787.

35. te Velthuis AJ, van den Worm SH, Sims AC, Sims AC, Baric RS, Snijder EJ, et al. 2010. Zn(2+) inhibits coronavirus and arterivirus RNA polymerase activity in vitro and zinc ionophores block 
medRxiv preprint doi: https://doi.org/10.1101/2021.07.06.21259924; this version posted July 7, 2021. The copyright holder for this preprint (which was not certified by peer review) is the author/funder, who has granted medRxiv a license to display the preprint in perpetuity. All rights reserved. No reuse allowed without permission.

the replication of these viruses in cell culture. PLoS Pathog. 6(11):e1001176. https://doi.org/10.1371/journal.ppat.1001176.

36. Samad N, Sodunke TE, Abubakar AR, Jahan I, Sharma P, Islam S, et al. 2021. The Implications of Zinc Therapy in Combating the COVID-19 Global Pandemic. J Inflamm Res. 14:527-50. https://doi.org/10.2147/JIR.S295377.

37. Hashim HA, Maulood MF, Rasheed AM, Fatak DF, Kabah KK, Abdulamir AS. 2020. Controlled randomized clinical trial on using Ivermectin with Doxycycline for treating COVID-19 patients in Baghdad Iraq. medRxiv. https://doi.org/10.1101/2020.10.26.20219345

38. Jans DA and Wagstaff KM. 2020. Ivermectin as a Broad-Spectrum Host-Directed Antiviral: The Real Deal? Cells. 9(9); 2100. https://doi.org/10.3390/cells9092100.

39. Muñoz J, Ballester MR, Antonijoan RM, Gich I, Rodríguez M, Colli E, et al. 2018. Safety and pharmacokinetic profile of fixed-dose ivermectin with an innovative $18 \mathrm{mg}$ tablet in healthy adult volunteers. PLoS Negl Trop Dis. 12(1):e0006020. https://doi.org/10.1371/journal.pntd.0006020.

40. Ohe M, Furuya K, Goudarzi H. 2021. Multidrug treatment for COVID-19. Drug Discov Ther. 15(1):39-41. https://doi.org/10.5582/ddt.2021.01005.

41. Lawrie TA. 2021. Ivermectin reduces the risk of death from COVID-19 -a rapid review and metaanalysis in support of the recommendation of the Front Line COVID-19 Critical Care Alliance. https://doi.org/10.13140/RG.2.2.27751.88486.

42. Huang DT, McVerry BJ, et al. 2021. The UPMC REMAP-COVID Group, on behalf of the REMAP-CAP Investigators, Implementation of the Randomized Embedded Multifactorial Adaptive Platform for COVID-19 (REMAP-COVID) trial in a US health system-lessons learned and recommendations. Trials 22, 100. https://doi.org/10.1186/s13063-020-04997-6. 
medRxiv preprint doi: https://doi.org/10.1101/2021.07.06.21259924; this version posted July 7, 2021. The copyright holder for this preprint

Figure and table legends:

Table 1: Listing of subjects and COVID-associated symptoms on presentation and other characteristics. $\mathrm{O}_{2} \% \mathrm{Sat}=\mathrm{SpO}_{2}$ just before time of treatment initiation. $\mathrm{O}_{2} \%$ Sat post 24 hrs. $=$ $\mathrm{SpO}_{2} 24$ hrs. after treatment initiation. Rx Start date $=$ Day 1 of ICT administration. $\mathrm{SOB}=$ Shortness of Breath

Table 2. A. Age and demographics of subjects. B. Prevalence of COVID susceptible comorbidities. C. Number of concurrent comorbidities in subjects.

Figure 1: Complete recovery was seen in all patients within 1 to 3 weeks.

A. Time in days to various stages of symptom onset and resolution.

Nearly all subjects resolved symptoms and became PCR negative in 3 weeks

Col 1: Symptom onset to start of treatment $(n=23$, mean $=9.17 \pm 2.05)$

Col 2: Start of treatment to resolution of symptoms. $(n=23$, mean $=11.61 \pm 1.38)$

Col 3: First PCR positive to first PCR negative $(\mathrm{n}=10$, mean $=16.90 \pm 1.58)$

Col 4: Start of treatment to first PCR negative $(n=10$, mean $=11.50 \pm 1.60)$

B. Top, $100 \%$ survival rate was seen in patients, which is significantly higher $\left(p=0.044\right.$ via $\chi^{2}$ test) than synthetic control from CDC database of equivalent or less COVID-vulnerable subjects. Bottom, No $(0 \%)$ patients required hospitalization, which is significantly less $\left(p=0.0011\right.$ via $\chi^{2}$ test) than synthetic control from database.

Figure 2. A. $\mathrm{O}_{2}$ saturation prior to treatment was significantly $(p<0.05)$ less than $95 \%$, the defined successful treatment reached by all subjects. B. $\mathrm{O}_{2}$ saturation significantly increased in subjects 24 hours after treatment (paired $t$-test, $p<0.001$, only subjects with data before and after treatment included). $\mathrm{O}_{2}$ saturation continued to rise, and until the defined cure of greater than $95 \% \mathrm{O}_{2}$ saturation.

Figure 3: Ambulatory COVID scores, Covidex and Covidex-F (see methods for definition; Covidex-F includes fever measure) vs. time from start of treatment to symptom resolution. There 
medRxiv preprint doi: https://doi.org/10.1101/2021.07.06.21259924; this version posted July 7, 2021. The copyright holder for this preprint (which was not certified by peer review) is the author/funder, who has granted medRxiv a license to display the preprint in perpetuity.

All rights reserved. No reuse allowed without permission.

was significant relation between either Covidex score (Covidex, $p=0.0288$; Covidex-F, $p=$ 0.0096) and treatment resolution time.

Supplementary Figure 1: Example of symptom log sheet used by subjects. 
medRxiv preprint doi: https://doi.org/10.1101/2021.07.06.21259924; this version posted July 7, 2021. The copyright holder for this preprint

(which was not certified by peer review) is the author/funder, who has granted medRxiv a license to display the preprint in perpetuity. All rights reserved. No reuse allowed without permission.

\section{Figures and Tables:}

\section{Table 1:}

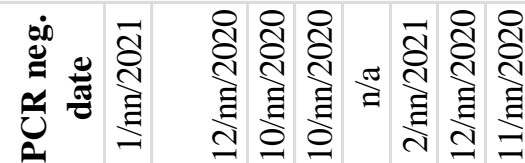

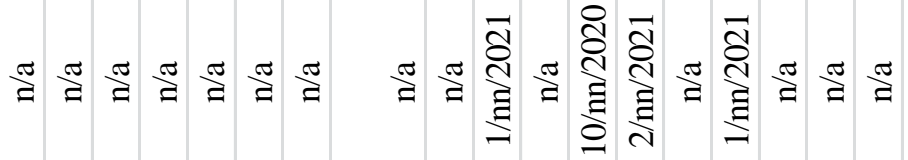

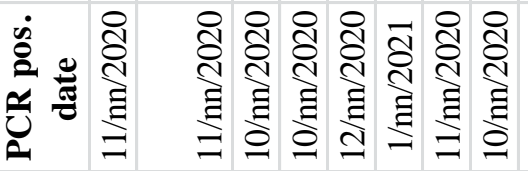

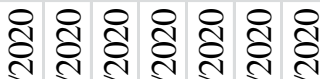

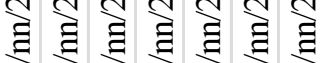

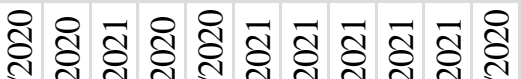
ป

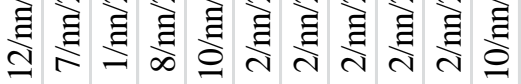

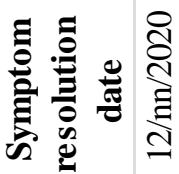

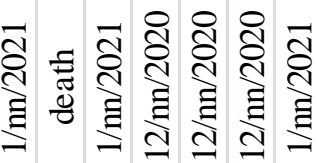

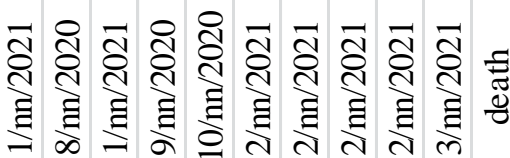

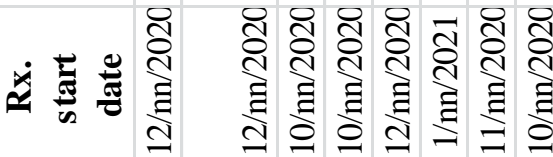

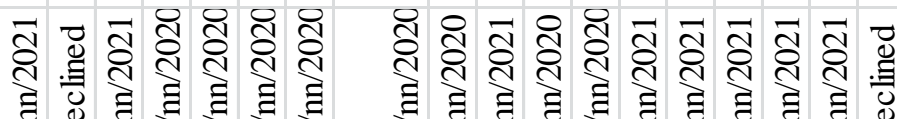

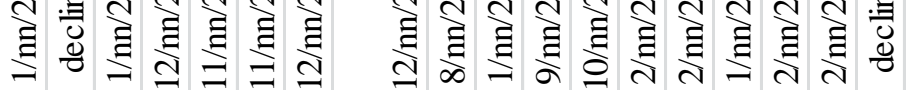

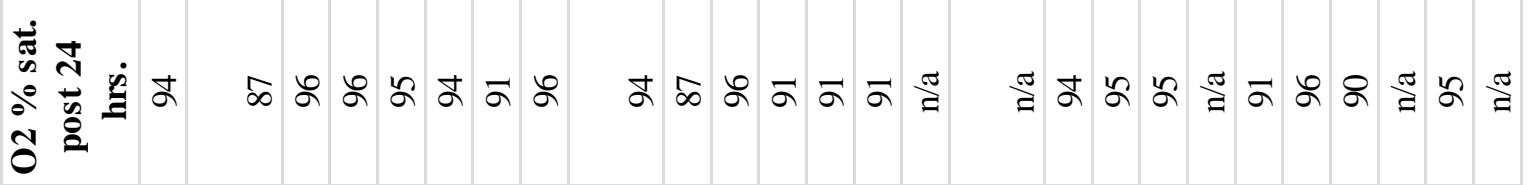

ర゚

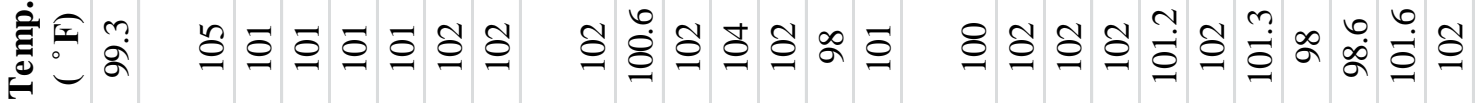

\begin{tabular}{|c|c|c|c|c|c|c|c|c|c|c|c|c|c|c|c|c|c|c|c|c|c|c|c|c|}
\hline 气̊ & 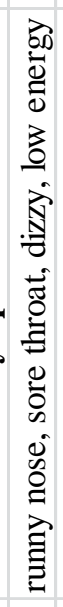 & 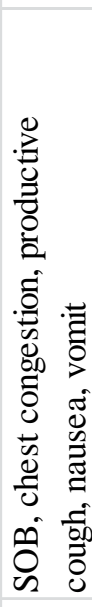 & & 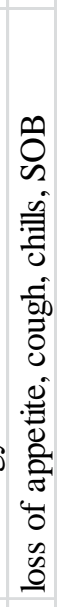 & 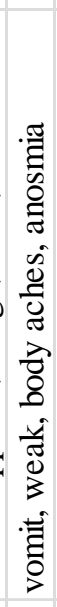 & 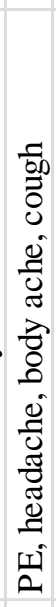 & 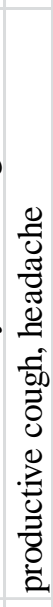 & 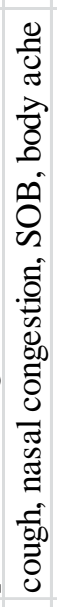 & 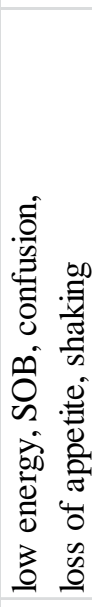 & 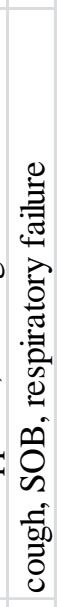 & 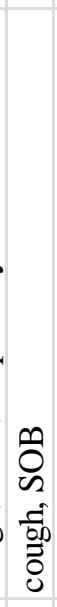 & & 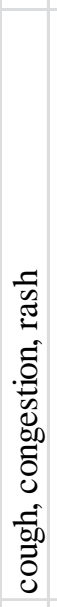 & 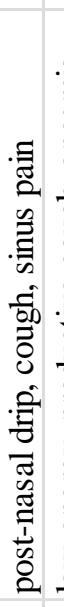 & 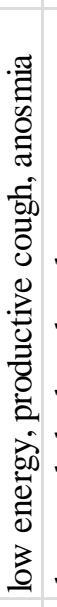 & 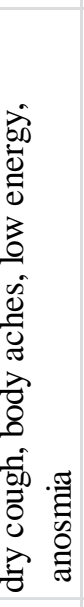 & 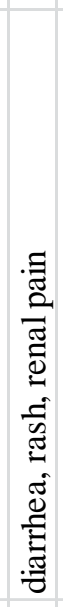 & 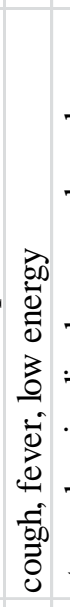 & 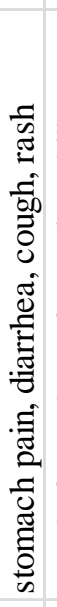 & 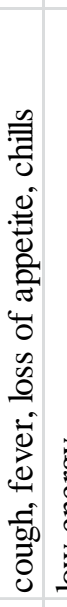 & 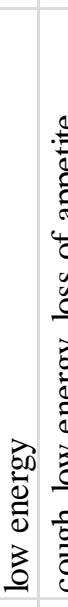 & 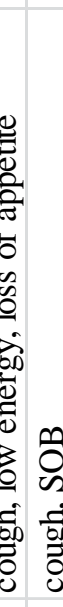 & $\begin{array}{l}0 \\
0 \\
0 \\
0 \\
0 \\
0 \\
0 \\
0 \\
0 \\
0 \\
0 \\
0 \\
0\end{array}$ & 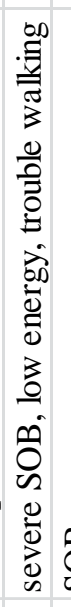 \\
\hline 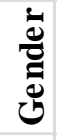 & $\Sigma$ & $\Sigma$ & $\Sigma$ & LI & I & L & $\Sigma$ & $\Sigma$ & I & $\Sigma$ & $\omega$ & $\Sigma$ & L & $\Sigma$ & $\Sigma$ & L & 工 & $\sum$ & 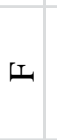 & $\Sigma$ & $\Sigma \Sigma$ & $\Sigma \Sigma$ & L & $\Sigma$ \\
\hline 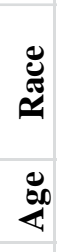 & 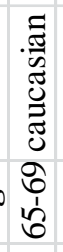 & 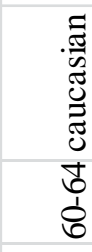 & 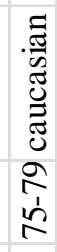 & 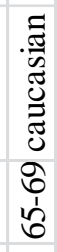 & 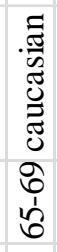 & 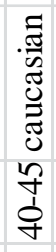 & 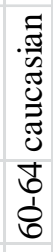 & 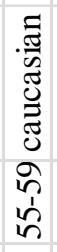 & 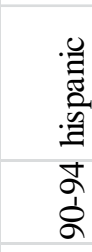 & 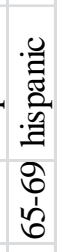 & 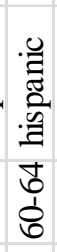 & $\begin{array}{l}\vec{a} \\
\stackrel{9}{q} \\
\stackrel{2}{f}\end{array}$ & 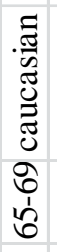 & 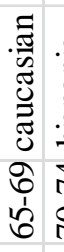 & 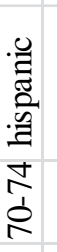 & 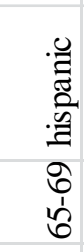 & 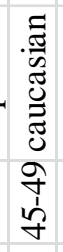 & 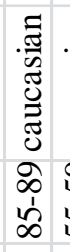 & 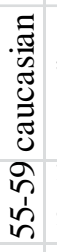 & 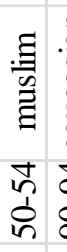 & 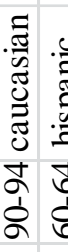 & 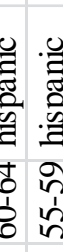 & 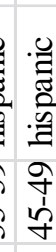 & 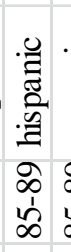 \\
\hline O & - & $\sim$ & $m$ & $\nabla$ & $n$ & 0 & $r$ & $\infty$ & $a$ & 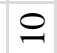 & $=$ & $\simeq$ & & $\pm y$ & $\because$ & $\mathscr{0}$ & 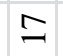 & $\infty$ & & तి & & 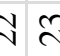 & J & ฉั \\
\hline
\end{tabular}


medRxiv preprint doi: https://doi.org/10.1101/2021.07.06.21259924; this version posted July 7, 2021. The copyright holder for this preprint (which was not certified by peer review) is the author/funder, who has granted medRxiv a license to display the preprint in perpetuity.

All rights reserved. No reuse allowed without permission.

Table 2:

A. Age (mean, SEM, range) 66, 2.75, 43 - 94

Male (n, \%)

$15,62.5 \%$

Female (n, \%)

$9,37.5 \%$

Race (n, \%)

Caucasian $\quad 14,58 \%$

Hispanic Mexican $\quad 7,27 \%$

South American $\quad 2,8 \%$

Other $1,4 \%$

B.

Comorbidity

Type 2 diabetes mellitus

Heart or cardiovascular COPD

Obesity (BMI 30 - 40)

Severe Obesity $(\mathrm{BMI} \geq 40)$

Chronic kidney disease

Immunocompromised state

C.

\section{\# of co-morbidities}

0

1

2

3

$\begin{array}{cc}\begin{array}{c}\text { \# of } \\ \text { subjects }\end{array} & \begin{array}{c}\text { \% of } \\ \text { subjects }\end{array} \\ 6 & 25.00 \\ 5 & 20.83 \\ 3 & 12.50 \\ 3 & 12.50 \\ 2 & 8.33 \\ 1 & 4.17 \\ 1 & 4.17\end{array}$

$\begin{array}{cc}\begin{array}{c}\text { \# of } \\ \text { subjects }\end{array} & \begin{array}{c}\text { \% of } \\ \text { subjects }\end{array} \\ 13 & 54.17 \\ 6 & 25.00 \\ 3 & 12.50 \\ 2 & 8.33\end{array}$


medRxiv preprint doi: https://doi.org/10.1101/2021.07.06.21259924; this version posted July 7, 2021. The copyright holder for this preprint (which was not certified by peer review) is the author/funder, who has granted medRxiv a license to display the preprint in perpetuity.

Figure 1:

A.

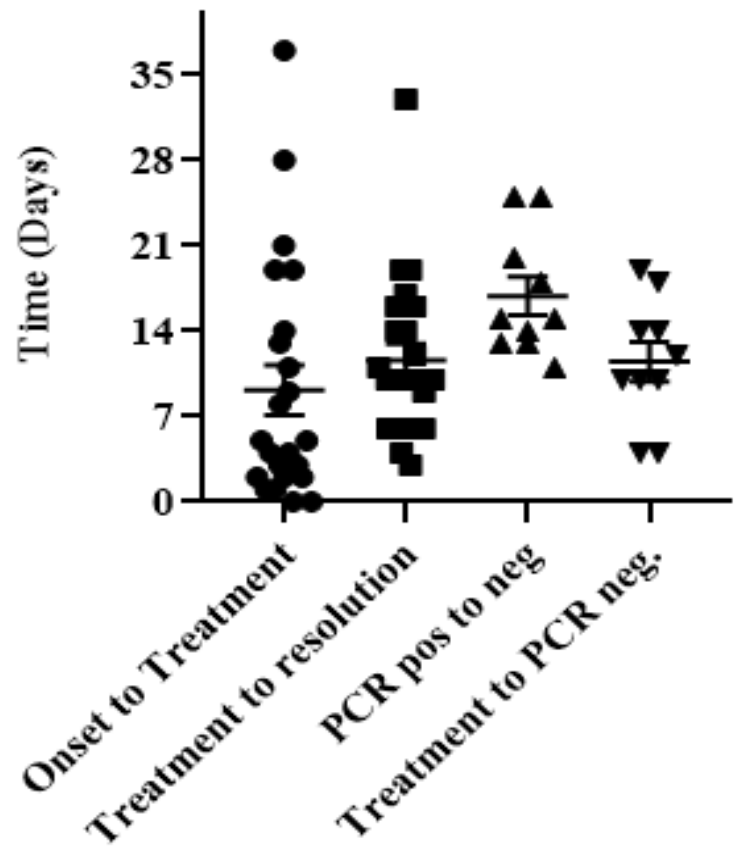

B. Ivermectin Combined

$\underline{\text { Real-World Care }}$

Therapy

Survived

$(n=24 / 24)$

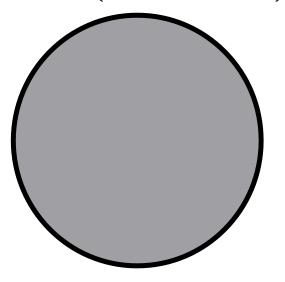

Deceased

$(n=45,369 / 313,805)$

Survived

$(\mathrm{n}=\mathbf{3 0 6 , 8 0 5} / \mathbf{3 1 3 , 8 0 5})$

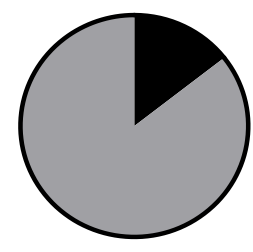

$p=0.044$

Hospitalized

$(\mathbf{n}=96,129 / 313,805)$

Non-Hospitalized

Non-Hospitalized

$(n=24 / 24)$ $(\mathrm{n}=217,676 / 313,805)$
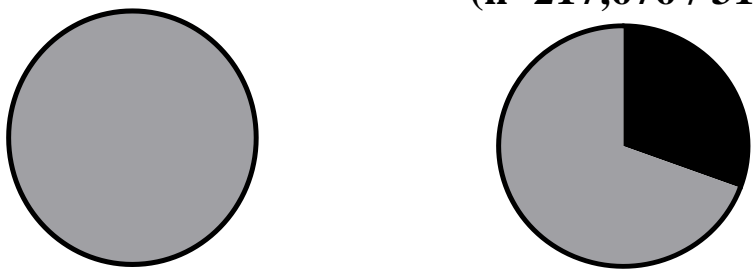

$p=0.0011$ 
medRxiv preprint doi: https://doi.org/10.1101/2021.07.06.21259924; this version posted July 7, 2021. The copyright holder for this preprint (which was not certified by peer review) is the author/funder, who has granted medRxiv a license to display the preprint in perpetuity.

All rights reserved. No reuse allowed without permission.

Figure 2:

A.

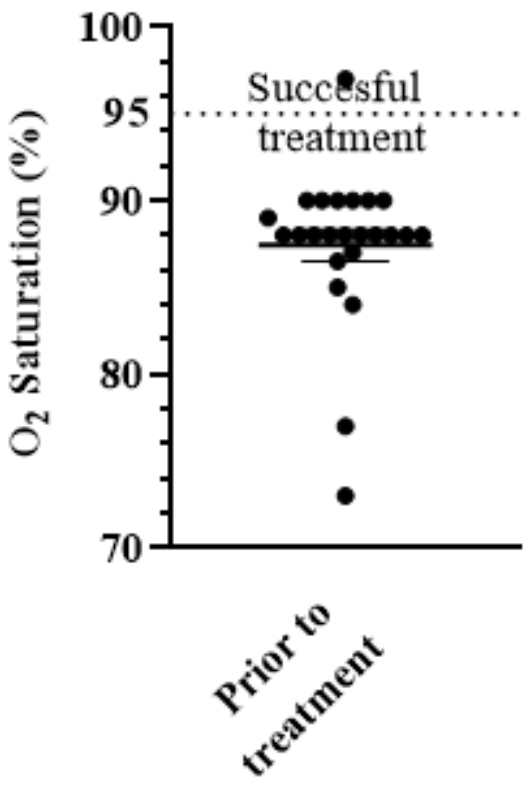

B.

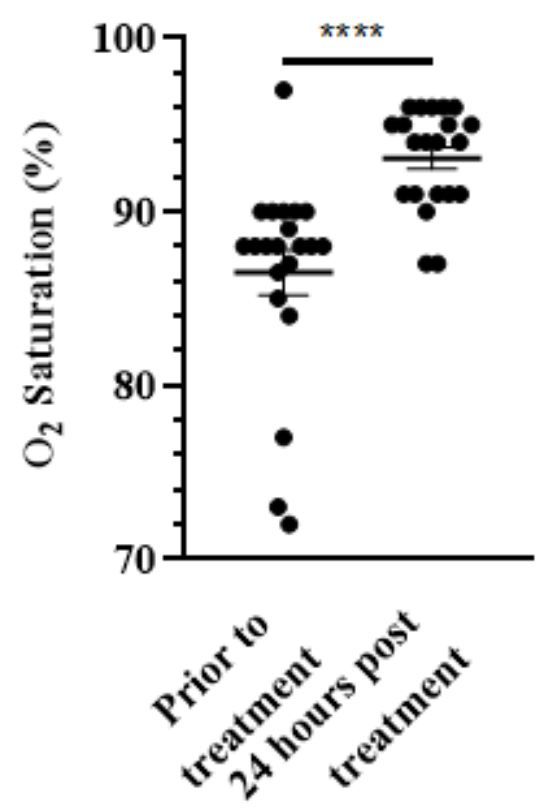


medRxiv preprint doi: https://doi.org/10.1101/2021.07.06.21259924; this version posted July 7, 2021. The copyright holder for this preprint (which was not certified by peer review) is the author/funder, who has granted medRxiv a license to display the preprint in perpetuity.

All rights reserved. No reuse allowed without permission.

Figure 3:

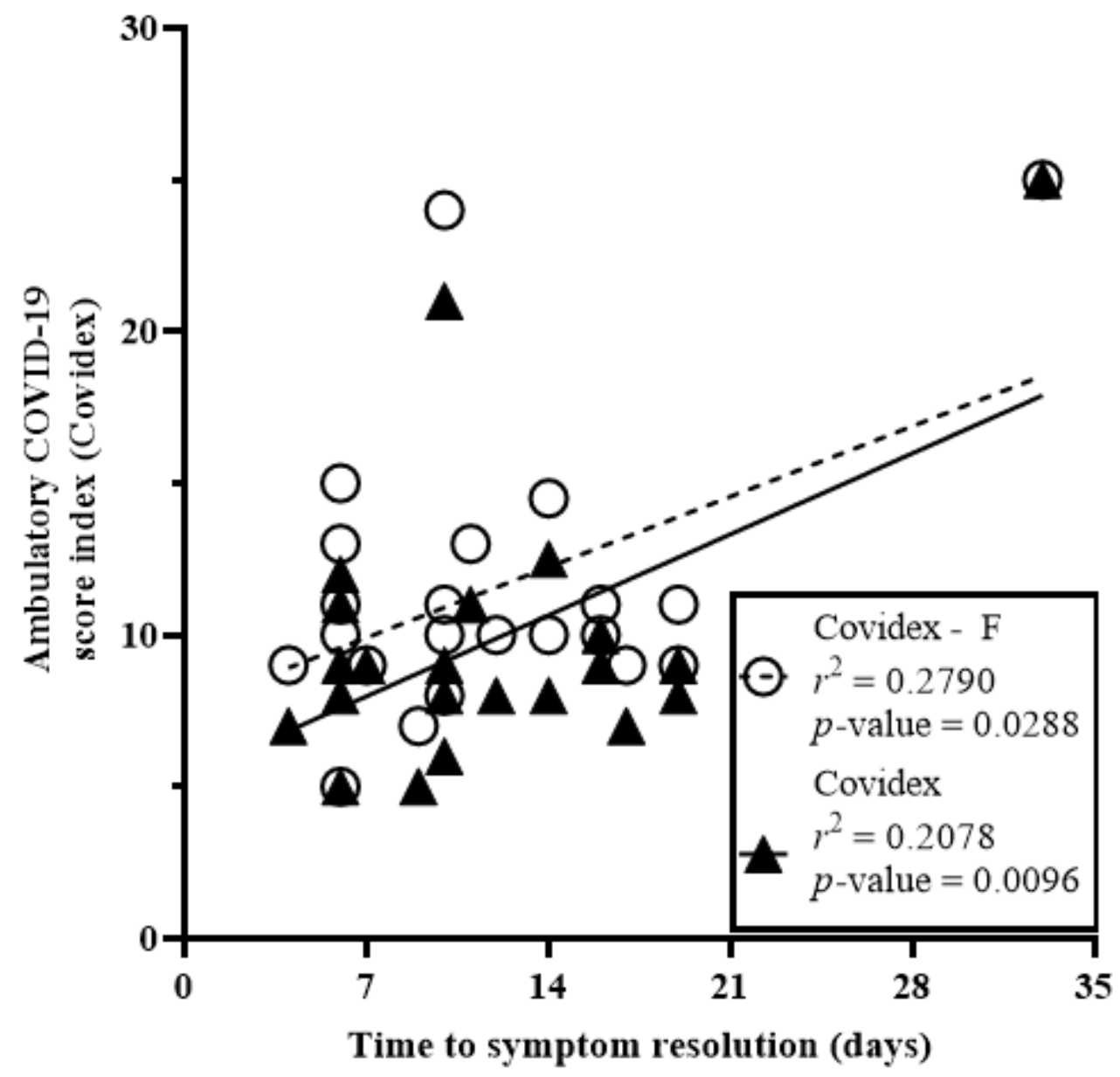


Supplementary Figure:

\section{Supplementary Figure 1:}

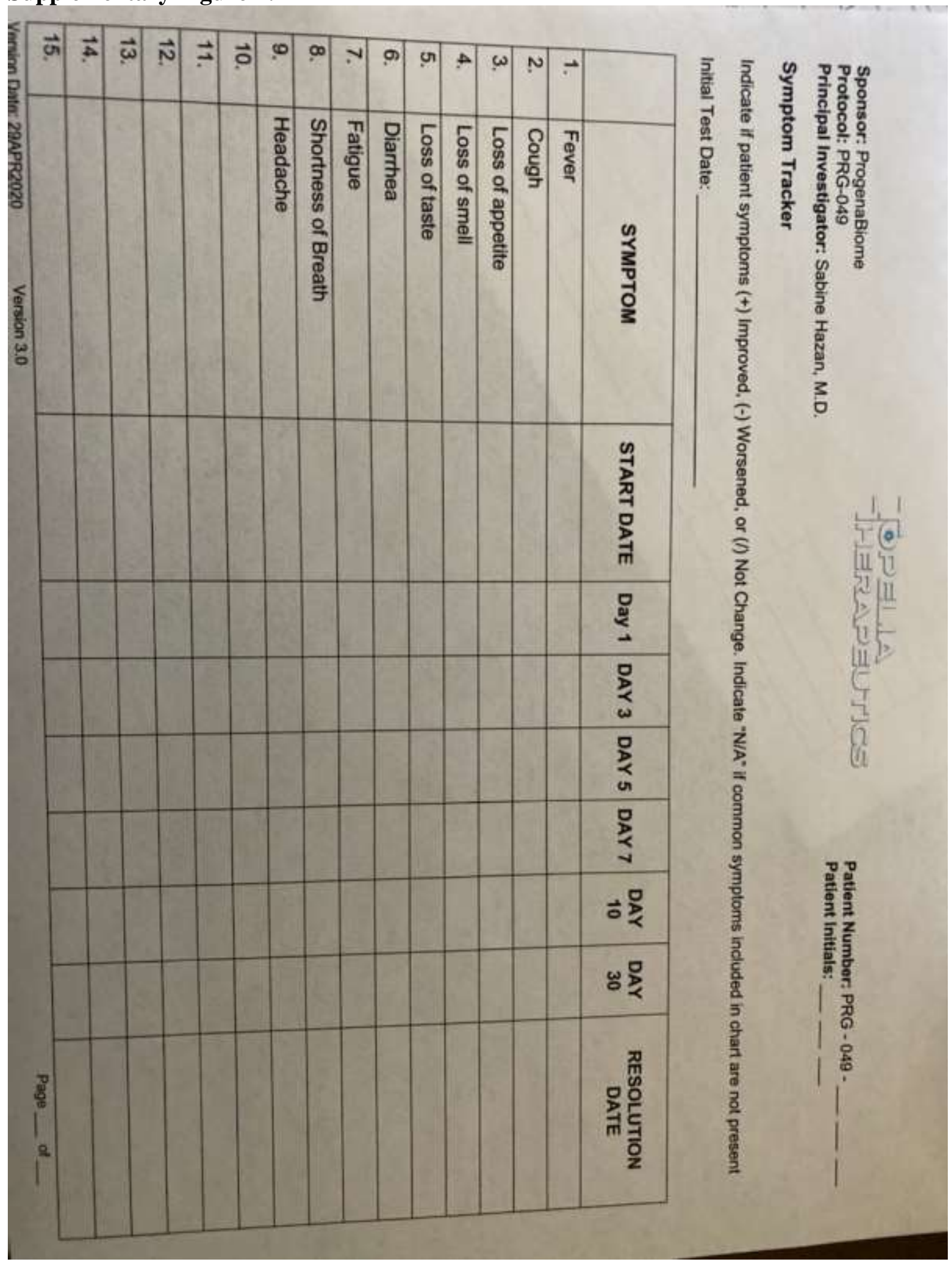

